Svitlana Rohotchenko

art researcher, postgraduate student, Modern Art Research Institute of the National Academy of Arts of Ukraine
Світлана Роготченко

мистецтвознавець, аспірантка, ІПСМ НАМ України

e-mail: tsv-inform@ukr.net orcid.org/0000-0002-6353-8591

\title{
Blacksmithing Art in the Eastern Ukraine as a Component Part of Ukrainian Cultural Process
}

\author{
Художне ковальство сходу України \\ як скмадова вітчизняного культурного процесу
}

\begin{abstract}
The development of art and craft of blacksmithing in the Eastern region of Ukraine, specifically in Poltava, Kharkiv, Dnipropetrovsk, and Donetsk oblasts has been analysed. The study of the blacksmithing in Donetsk city and Donetsk oblast was limited to the second half of the $19^{\text {th }}$ century and up to the 2014. The progress of blacksmithing at the temporarily occupied and uncontrolled territories of Ukraine has not been researched by the author. The article focuses on the unique piece blacksmithing art of the national and global scale - Mertsalov palm tree. In 1900 Mertsalov palm tree was displayed at the 1900 Paris Exposition in the pavilion of the coal society. In 1999 the first copy of the Mertsalov palm tree was mounted in Donetsk. This latter palm tree was forged by the Donetsk-based smith Serhiy Kaspruk along with his son Oleh. Mertsalov palm tree became the first contemporary art piece turning the public attention not only to the artwork itself, but to the producing enterprise as well. From the contemporary marketing viewpoint the forged palm tree on display was an event of unprecedented global scope. Mertsalov palm tree was a starting point for the development of blacksmithing art in the Eastern Ukraine that survived the decay during the harsh $20^{\text {th }}$ century and was revived during the early 1980s.
\end{abstract}

Keywords: blacksmithing, Mertsalov palm tree, marketing, Park of Forged Figures.

Objectives of the study are to highlight the issues that emerged during the blacksmithing art revival in the Eastern Ukraine.

Problem statement in general and its connection with important scientific or practical tasks. There has been a long history of blacksmithing in the Donetsk region and around, in the first place due to the mineral deposits, developed by the numerous ventures of the region. The second component part in the development of the blacksmithing craft was a large number of the mine forges that produced the equipment for the mining industry. The author researches the history of creation of the world-renowned art piece-Mertsalov palm tree-and draws an outline of revival of the contemporary blacksmithing art in the Eastern Ukraine. The author has been studying the history of Ukrainian and European blacksmith art for five years, while working as an art expert at the Tantiema, LLC, Kyiv-based factory of Metalwork art. Research of the development processes of the blacksmithing craft in general and of the blacksmithing art in particular is conducted in accordance with the research plan for the Candidate's thesis "Blacksmithing art of the Central Ukraine from the 1970s till 2010”, approved at the meeting of the Academic Council of the Modern Art Research Institute of the National Academy of Arts of Ukraine, held on 03.19.2019.
Analysis of recent research works and publications. The processes of reviving an ancient blacksmithing art and craft after the forced break from the 1930s to the 1970s still lacks proper research. The present state of research is even more dim when it comes to the blacksmithing art centers of the Eastern Ukraine, where the blacksmithing craft was completely eradicated. There are still many blank pages in the history of emergence of Ukrainian blacksmithing school, development of which was in no way similar to the comparable processes that took place in the Western Europe, Moldova, Belarus, Russia, and in the Baltic states. Only during the last two decades have the researchers of art and culture, historians and journalists expressed interest in studying the blacksmithing art. As of today, the number of research works on the metalwork issued in the specialized periodicals, as well as the number of Master's and Candidate's theses on the subject, significantly increased. In 2018 the Master's thesis “Blacksmithing art in Ukraine during the independence era" by Mykhailo Berdysh was defended at the National Academy of Fine Art and Architecture; in May 2017 the Candidate's thesis "Art jewelry in Ukraine from the last third of the $20^{\text {th }}$ century till the early $21^{\text {st }}$ century: European context, creative features, figures" by Martha Kravchenko was defended at the Lviv National Academy 
of Arts. Publications on the challenges of blacksmithing are often featured in the periodicals of the National Union of Artists of Ukraine, i.e. Obrazotvorche Mystetstvo [Fine Art], and in the MIST collected papers, issued by the Modern Art Research Institute. A number of publications were issued in Donetsk and Ivano-Frankivsk. Still, despite the increase in number of specialized periodicals, including 24 caraty [ 24 Carats], Yuvelirnyi Visnyk [Jewelery Journal], Mir Metalla [The World of Metal], Kovalska Maisternia [Blacksmithing Workshop] (only the latter has been issued up to date) that covered the challenges of blacksmithing the vast majority of articles were popular magazine style and not scholarly publications. Essential for the current research are the studies, published in the specialized All-Ukrainian Zhurnal o metalle [Journal on Metal], the printed version of which was issued in Donetsk during 2004-2009 and which went on to be issued digitally as a web-journal Site o metalle [Web-site on metal]. Zhurnal o metalle [Journal on Metal] was established on the $9^{\text {th }}$ April, 2004 by the Gefest founder Victor Burduk. Ihor Rudenko, a writer, journalist, and art researcher, was appointed an editor-in-chief. "The metal theme is everlasting. It is most topical for Ukraine that has metal industry and metalwork as its business card at the international market." [5, p. 3] The analytical research of the blacksmithing art and craft in Donetsk region during the contemporary time was conducted by Andriy Rybas and featured in the special issue of Zhurnal o metalle [Journal on Metal] (2005, issue 3-4(6). The article, titled "The seventh traditional AllUkrainian festival of blacksmithing art in Donetsk", traced the parallels in the development of contemporary blacksmithing in Donetsk with the organizing of the unique Park of Forged Figures. In 2005, then-president of Ukraine Victor Yushchenko took part in both the city day celebrations and in the grand opening of the blacksmithing festival [6]. Andriy Rybas also authored a material "Where does the power the Golden Pectoral come from?” The article focuses on the ancient Scythian artifact discovered by Borys Mozolevskyi. This material is of a great value for the current research, as it showcases the real timeline of emergence and development of the contemporary art of ironwork, repoussй and chasing in Ukraine.

Serhiy and Olga Polubotko made on overview of the $16^{\text {th }}$ European Biennial of Blacksmithing Art in Stia that attracted the very best European blacksmiths, including the Ukrainian masters [8]. The material was featured in Zhurnal o metalle [Journal on Metal] as well.

Svitlana Andrushenko contributed several materials. The first one- "Excellence of the Forged Furniture"- professionally argues about the advantages of the forged furniture in the contemporary interior design [9]. The second article- "Smith: A Legendary Figure"- provides an art research and philosophical considerations on the role of a blacksmith since the times of Ancient Greece till the present day. The text is rich in little-known historical data [10].

Since the 2005 the Zhurnal o metalle [Journal on Metal] has an Art Research section. The editorial board of the journal, therefore, aims not only to inform the reader but to study the ancient art of smithing from the scientific standpoint. Editorial material "Hephaestus' Business is a Phoenix Bird" clearly illustrates such attitude. The research covers the period of over 100 years (since the turn of the $20^{\text {th }}$ century until the early $21^{\text {st }}$ century) and explains the stages of development and decline of the blacksmithing art, repoussŭ and chasing in Ukraine generally and in Donetsk region in particular.

In 2007 the Donetsk-based publishing house "Region" Utility Enterprise issued the landmark book for UkraineBlacksmithing Art of Ukraine. Part 1. Revival, authored and compiled by Ihor Rudenko. The foreword states: "This is the first publication on the artist blacksmithing of such a high level that has been issued in Ukraine. The edition features the works of the masters from the different regions of the country, their trademark works, reflections, samples of architectural and applied art solutions. The publication is aimed at a non-specialist audience." The 120-paged full-color edition tells a detailed story of the achievements of the best smithing enterprises and individual artist blacksmiths of Ukraine. Several hundred illustrations give a comprehensive overview of the matured national blacksmithing art [18].

The study of the processes of elimination, revival, and further development of Ukrainian blacksmithing would not be possible without the profound research works of Oleksandr Fedoruk, Rostyslav Shmagalo, Serhiy Bilan, Martha Kravchenko, Emilia Sydor, Roman Strynadiuk, Halyna Stelmaschiuk, Iryna Gaimus, Volodymyr Nediak, Illya Popiuk, Liubov Lysenko, Natalia Sukhorska, Roman Yatsiv, Roman Konovalov.

Presentation of the main research material. Donets Basin is the most significant region of coal and metal ore mining, of metal production in Ukraine. "1869 is considered the official date of the founding of Donetsk, as this was the year of founding of Yuzivka village by the Welsh businessman John Hughes. Hughes started the construction of the ironworks along with the workers' settlement near Oleksandrivka village. Amid the construction of the ironworks and mines, Oleksadrivka village was gradually replaced by Yuzivka or Hughesove - 'a posad with the simplified public administration." In 1916 the Putilov Ironworks factories were established based on the former mechanical workshops along the railroad. That year two coking plants were founded as well: Rutchenkivkyi (142 blast furnaces) and Mushtetivskyi (408 blast furnaces) [4, p. 11]. Prior to World War I there were over 1200 mines operating in the Donets basin. Their productive capacity was over 21000 tons a year [3]. The rapid development of the region since the 1870 s prompted the emergence of mine forges. The forges produced the equipment, necessary for underground and surface works. There was a great need of crow-bars, spades, pickaxes and more specific instruments. The number of forges in the Donetsk region was significantly higher than in other areas of Ukraine.

The blacksmithing art of the turn of the $21^{\text {st }}$ century in the Donetsk region is well-known today mostly due to the unique piece of blacksmithing art-Mertsalov palm tree that in 1985 was forged out of a steel rail by the smiths 
of the Yuzivka factory of the Novorussian Society for Coal, Iron and Rail Production: Oleksiy Mertsalov, an artist blacksmith, Pylyp Shkarin, a blacksmith's striker, and by other factory workers [3]. This work of metal art was specifically designed for display at the 1896 All-Russia Industrial and Art Exhibition in Nizhny Novgorod. It received the highest award from the viewers and experts. The Kharkiv magazine Metallurgical Bulletin described the piece after the closure of the exhibition: "The palm tree is forged out of a single piece of rail. Its stem has ten leaves and is surmounted by a crown. This true work of art is $3.53 \mathrm{~m}$ high. A hammer and a chisel are the only instruments used by the blacksmiths" [14].

The press of the time as well as the further studies claimed that the artwork was forged out "of a single piece of rail" [3]. In reality, it was not. The rail was chosen as a source material. The main goal and task of the artwork was advertising the products of the Novorussian Society for Coal, Iron and Rail Production. The top of the palm tree, serving as a visual center of the artwork, is surmounted with the crown; ten wrought leaves are designed around the stem that form a unified spatial composition with the vertical dominant. The palm tree "grows" out of a forged barrel. The supporting structure that held the over $3 \mathrm{~m}$ high artwork together were maid of rails as well. Twenty three metal hoops of different diameters were used for axillary support. The number of hoops hinted on the number of years of enterprise operation. Namely, the plant would be in operation for 23 years in 1896 . The tree itself weighted $325 \mathrm{~kg}$, while the barrel-200 kg.

In 1900 Mertsalov palm tree was displayed at the 1900 Paris Exposition in the pavilion of the Novorussian Society for Coal, Iron and Rail Production. Mertsalov palm tree receives a grand prix of the Exposition. It was the highest award for an artwork during the era. In 1900, after the closure of the exhibition, the palm tree and the mine model were transfered for display to the museum of the Saint Petersburg Mining University, where the original artwork is stored up to this day.

The research of the unique piece of metal art was conducted in the 1950s. At the time the researchers came to a conclusion that Mertsalov palm tree was forged out of a single piece of rail. The next investigations were carried out in the 2000s. The structural and molecular expert examinations, as well as an $\mathrm{x}$-ray scan proved the artwork to be made out of several segments, joined with the fusion welding [17]. The history of a forged artwork by Oleksiy Mertsalov lasts up to this day. "The image of the Mertsalov palm tree was adopted as a symbol of Ukraine's revival; the initiative was set forth by the Zolotyi Skif Donetsk regional foundation" [15].

On the 12 September, 1999 the first copy of the Mertsalov palm tree was mounted at the square near the Expo-Donbas exhibition center. This copy is there up to this day. It is shielded with the protective glass dome. The artwork is $4.20 \mathrm{~m}$ high. This palm tree was forged by the Donetsk-based artist blacksmith Serhiy Kaspruk. Among his aids were his son Oleh and several other blacksmiths from Donetsk, who worked together for 3.5 month to produce this piece of metal art.
The material for the copy was provided by the Lidiyivska mine: a rail with the marking: "1901 S.E. R." [South Eastern Railroad]. There is no preserved archive records of Oleksiy Mertsalov's technique. Thus, Serhiy Kaspruk had to invent a technique of his own. The rail workpiece was covered with coal and heated up in a forge. On the spots where the leaves were designed to be, the indents were made that were heated in the furnace during the subsequent operations and shaped with the chisel and hammer. The pieces of the artwork were heated approximately 10000 times. Serhiy Kaspruk produced several subsequent copies, which were mounted in Kyiv and Moscow. According to the initial design, this copy should have become one of the exhibits of the Donesk national museum of the industrial history of Ukraine, however, the idea never came into being. In May 2001, the copy of the Mertsalov palm tree was gifted to the city of Kyiv to commemorate the $10^{\text {th }}$ anniversary of the independence of Ukraine. This copy of $3.55 \mathrm{~m}$ high. In return, Kyiv authorities gifted the monument of the Archistratigus Michael to the city of Donetsk. It was initially planned to mount the monument at the Maidan Nezalezhnosti, however later on the palm tree was moved and mounted near the Globus shopping center.

"In December 2002 the copy of Mertsalov palm tree was gifted to the city of Ottawa within the framework of the Canadian Leaves festival. On 10 April, 2003 the copy of Mertsalov palm tree was gifted the the city of Hanover and mounted at the central hall of the Hanover Exhibition Centre. The copy of Mertsalov palm tree in Lviv was mounted at the square in front of the local railway station in May 2003. In Kyiv the copy of the Mertsalov palm tree was temporary mounted in January 2004 within the territory of the Kyiv Pechersk Lavra and subsequently this copy was transferred to Jerusalem. Also, in 2004 two copies of the palm tree were gifted to the city of Kharkiv to commemorate its $350^{\text {th }}$ founding anniversary. One was mounted at the Palace of Sports; another-at the Cultural Activities Center of the Yaroslav Mudryi National Law University. Moreover, one Mertsalov palm tree was mounted in Iraq to commemorate the reopening of the Ukrainian embassy and another, amid plans to move it to the one of the Le Bourget salons, eventually was mounted at the Boryspil International Airport in Kyiv" [13].

In 2007, within the celebration of the Donetsk oblast $75^{\text {th }}$ anniversary, another copy of Mertsalov palm tree was mounted at the Pushkin boulevard in Donetsk. This copy was forged by the blacksmith Yevhen Yermak of the damascus steel at the Gefest, a Ukrainian blacksmithing enterprise managed by Victor Burduk.

Forged Mertsalov palm tree drew attention to the products of the Novorussian Society for Coal, Iron and Rail Production. At the same time, the artwork was so profoundly powerful and influential that even 100 years later it gave impetus for the revival of the blacksmithing art both within the Donetsk region and in Ukraine overall.

The author interviewed Victor Burduk, an Honored Worker of Arts of Ukraine, Head of the Union of the Artist Blacksmiths of Ukraine. 
Victor Burduk recounts, "Mertsalov palm tree, of the late $19^{\text {th }}$ century, is renowned from three viewpoints: 1 . It is exclusively hand-made. 2. It advertised the quality of the Yuzivka steel, produced at the Yuzivka factory. 3. It was made of a rail, however, it was cut in the process. The palm tree is made out of a rail with its details joined through forge welding. The slogan of the artwork is 'The possibility is proved by a deed"' $[11]$.

According to Victor Burduk testimony, there was no development of blacksmithing art during the post-war era at all. The revival of blacksmithing started only during the early 1990s. Donetsk has always been an industrial city. Each mine had a forge, where smiths produced crowbars, pickaxes, and hammers. More gifted blacksmiths were capable of making whirls. There were two award-winning blacksmiths in Donetsk in the 1990s: Oleksandr Lytvyn and Oleksandr Bilovol, both graduates of the Vera Mukhina Leningrad Higher School of Art and Industry that at the time had a Decorative Metalwork Department. Both artist blacksmiths were members of the Union of Blacksmiths of the USSR and participated in creation of the underground forged panel in Kharkiv subway. These two man had both had knowledge and specialized education. The 1990s were marked with the onset of changes both in the lives of Ukraine in general and Donetsk in particular. People felt an urgent need in decorating their dwellings. The need for beauty was in the air. Therefore, Victor Burduk along with Ihor Loshadkin and Volodymyr Sosedko started their studies and practices of blacksmithing art. Victor Burduk founded his Gefest, the Salon of Decorative Metalwork, which was the first of a kind at the time in Ukraine. The masters forged spacial compositions, i.e. the bouquets for walls decoration, bars, balcony protection bars and balusters, chairs and even beds. An average person from the street, who had no chance of studying any foreign catalog, could just walk into the Salon and see with his own eyes the pieces of decorative metalwork. This boosted the business enormously. The Gefest creativity was regulated by whether or not certain piece was commissioned. The masters hardly had a spare minute for improvised compositions, nevertheless the latter were created despite the lack of time. In the mid-1990s an exhibition of ironwork was organized at the Nathnennia Research Guidance Center that worked rather with the masters, who were not professionals yet. Afterwards the National Union of Artists of Ukraine awarded Victor Burduk and Ihor Lozhkin with the honorable rank "Master of folk art".

The $2^{\text {nd }}$ Festival was held in 1998. After considerable brake the subsequent Donetsk Blacksmithing Festival was organized in 2001. Donetsk festivals became the starting point for the revival of blacksmithing art in the region and later resulted in the founding the Park of Forged Figures.

"Mertsalov palm tree, forged by our fellow countryman, a blacksmith from Donetsk, turned the attention of the global blacksmithing community to the Donets basin. From my point of view, if such phenomenon occurred somewhere in Germany, United Kingdom or United States, it would be mentioned in all the textbooks on blacksmithing.
Yet, we timidly kept it low-scale. Still, Oleksiy Mertsalov is a genius. I reckon that there would be many prolific studies of his work. His legacy unites millions of people from all around the world. This is actually what we need the most these days. I have always been and I remain an ardent believer in art to be powerful enough to stop the war and save the world" [11].

Donets coal basin as well as Donbas region generally during the Soviet times was one the most productive industrial regions of the country. In addition to the mining industry, the production of metal, metalwork, as well as clay mining and production of porcelain and faience flourished there. The number of plants and factories in the Donbas region could be counted in thousands. There were forges at most plants, factories, and mines. As it was previously mentioned, such forges produced the daily use products and tools. Naturally, the blacksmithing art was not on the agenda. As well as on the rest of the territory of the republic, there were sporadic non-factory commissions, mainly tomb fences and forged crosses. The first private ironwork enterprises started their operation in the mid-1990s. Their main area of specialization was production of bars and armored doors. General public had almost no notion of decorative meta; work whatsoever. Gefest was one of the first blacksmithing enterprises in Donetsk. Gefest was founded in 1994. One of the sell sheets of the time attested: "These days Gefest turned into the large and solid team of blacksmiths and designers, perfectly skilled in decorative ironwork, casting, welding and other technological stages of processing of metal." Gefest blacksmithing enterprise was also an art studio. The young professionals turned into true masters there: into skilled blacksmiths, designers, founders, and stained-glass designers. Gefest blacksmithing enterprise received numerous international awards and diplomas that proved the high level of its artistic mastery. At the time, the Blacksmithing Shop design studio was a library and a demonstration center for both the masters and visitors. The company had worked on many sites during its prolific blacksmithing history.

During its operation since 1994 till 2014 the Gefest blacksmithing enterprise performed a number of unique creative works. The Gefest enterprise over the years cradled a string of noted blacksmiths, including Mykola Hrymailo, Ruslan Mamisashvili, Yevhen Yermak, Ruslan Trachiuk, Vadym Tyschenko, Oleksandr Gurov, Andriy Sukhariev. Fitters Serhiy Stetsura, Oleksandr Levchenko, Mykola Shevchenko; Serhiy Popov, a sculptor, artists and a founder, Hryhoriy Havrysh, a stained-glass artist, Oleksandr Chernikov, a founder, worked for the business in different years. The majority of Gefest artworks were designed by Donetsk-based designers Andriy Beliaev and Margaryta Ternova, as well as by the Kyivites Valeriy Kasko and Mykola Herasymenko.

The competitor blacksmithing enterprises started their operation on the turn of the 2000s: Opal (Blacksmithing Manufacture) headed by Oleksandr Chubenko; Serhiy Kaspruk Studio, Andriy Bondarenko Studio (Kostiantynivka, 
Donetsk oblast). In the neighboring Dnipropetrovsk oblast blacksmithing enterprises also emerged, i.e. Pan Art (creative duo of Oleksandr Bezruchko, who specialized in small sculpture, and Dmytro Kushniruk, a master of titanium welding) and the Ptakh Studio Workshop. Ihor Shapoval from Kirovograd oblast founded a blacksmithing enterprise of its own and titled it Svarozhychi. The slogan of the business, formulated by Ihor Shapoval, was the following: "Blacksmithing craft is a serious collective undertaking, erected upon the talent of the natural genius of one master." Viacheslav and Dmytro Vovchuk founded their family blacksmithing studio in their home city of Kharkiv. Unfortunately, it remains practically sole blacksmithing center in Kharkiv, despite the leading role of the "first capital of Ukraine" in the sphere of design. Oleksandr Poturynskyi from Lubny starts operating as a private entrepreneur in the forge of his own. He specifically focuses on education of the young blacksmiths. The studio is in operation as of today. Oleksandr Poturynskyi's creative works are at all times marked with his high mastery. His compositions are logical and perfected. Poturynskyi's blacksmithing art exemplifies the prolongation of the traditions of his old profession. Petro Fedoriak produces unique ironwork pieces in his privately-owned forge in Trudoliub village of the Myrgorod Raion of the Poltava oblast. His works are one of a kind, as his sphere of interest is the art of Japan. Petro Fedoriak develops the blacksmithing areas that are practically unknown to Ukrainians, i.e. traditional Japanese blade weapons and ritual items. The master is still working as of today. Arthur Pogrebniak from Opishnia village of Zinkiv Raion of the Poltava Oblast organized a forge of his own as well.

The names of artist blacksmiths Yevhen Yermak, Mykhailo Vasyliev, Vitaliy Chernov, Andriy Bondarenko emerge at the horizon of the Eastern Ukrainian blacksmithing during the 2000s.

Yevhen Yermak entered the history of Ukrainian professional blacksmithing community as a winner of unique blacksmithing heptathlon held in Donetsk until the recent years.

The competition between Ukrainian blacksmiths was organized within the traditional blacksmithing festival. "An independent expert panel headed by Serhiy Polubotko from Ivano-Frankivsk rigorously counted the points and declared the results. Donetsk-based Yevhen Yermak and Anatoliy Ledniov from Crimea tied for the first place; the winning group of three was completed by Volodymyr Hrynchyshyn from the Western Ukraine. Yevhen Yermak, an artist blacksmith, says he did not have an exact goal to win the competition, instead he aimed to prove his hammering skill, as he has been inseparable from his forge hammer since he was 20 . He is currently mastering the new tool-a 45 kg sledgehammer" [18]. "Vitaliy Chernov, a blacksmith, was born in Yuriivka village of the Dobropillia Raion of Donetsk Oblast. After graduating from the Shylivka secondary school he enrolled into the Donetsk College of Culture. Upon graduation he worked at the Shylivka Center for Cultural Activities. In 1991, he organized a small forge at his private property. The first items he produced were the candle holders. Later on his hobby turned into a profession. Vitaliy Chernov started his own private business. Thus, his favorite occupation and profession were merged in one. Vitaliy Chernov is a master of the Blacksmiths Guild of Donbas, member of the Blacksmiths and Masters of Wrought Ironwork of Ukraine, a constant participant of the Park of Forged Figures International Blacksmithing Festival in Donetsk. He was a member of delegations that represented Ukraine at the blacksmithing festivals abroad; also he is an organizer of the festival 'Blacksmithing harvesting on the good field' in Shylivka [Dobropillia, the center of Dobropillia Raion, where Shylivka is situated, literally means 'a good field']. He has been awarded with various diplomas for his contribution to the development and promoting Ukrainian blacksmithing art. The master gifted a number of his works to his home village of Shylivka, as well as to the city of Donetsk. In 2013 Vitaliy Chernov created his first artwork, using a unique technique that combines wrought ironwork and elements of embroidery and knitting. These compositions were produced in collaboration with Nataliya Tsyganok and Victoria Kaverina” [19].

The Park of Forged Figures is a museum of contemporary blacksmithing art that has no precedents neither in Ukraine nor in Europe. The Park of Forged Figures in Donetsk is a unique art, sociocultural, political, and art phenomenon. Blacksmiths from all regions of Ukraine, as well as the foreign masters, contributed to the Park of Forged Figures. The culturological and art research analysis of the Park of Forged Figures would be a subject for further study.

Conclusions. The scenario of revival of the blacksmithing art in the Eastern Ukraine fundamentally differs from the ones of the Central, Southern and Western Ukraine. Blacksmithing expanded in the Donetsk region from the moment of colonization of the these lands. The number of forges in the Donetsk region was significantly higher than in other areas of Ukraine. The main reason for that were deposits of iron ore, the main component of the blacksmithing. Mertsalov palm tree, a creation of Oleksiy Mertsalov, a blacksmith from Donetsk, was exhibited at the 1900 Paris Exposition. The artwork received a grand prix. It was the highest award for the piece of metal art during the era. The first blacksmithing enterprise in Donetsk-Gefest-was established in 1994. It was the starting point for the rapid development of blacksmithing art in the region. The main achievement of the artist blacksmithing community, undoubtedly, is a unique Park of Forged Figures. Artist blacksmiths from all over Ukraine contributed to the creation of the Park of Forged Figures. The park not only organizes the space of the city square but became one of the bricks in the foundation of future Union of Blacksmiths of Ukraine and in the solid development of Ukrainian blacksmithing art. 


\section{References}

1. Berdysh M. Khudozhnie kovalstvo Ukrainy doby nezalezhnosti [dyplomna robota na zdobuttia stupenia mahistra]. Kyiv: NAOMA, 2018. 2. Bonkovska S. Khudozhnia obrobka metalu // Istoriia dekoratyvnoho mystetstva Ukrainy: U 5 t. / hol. red. H. Skrypnyk. Kyiv: NAN Ukrainy, IMFE im. M. T. Rylskoho, 2011. T. 4. S. 161-182.

3. Volkov F. Etnograficheskie osobennosti ukrainskogo naroda // Ukrainskiy narod v ego proshlom i nastoyaschem. Petrograd, 1916. T. 2 S. 486-579.

4. Haiko H., Biletskyi V., Mikos T., Khmura Ya. Hirnytstvo y pidzemni sporudy v Ukraini ta Polshchi (narysy z istorii). Donetsk: UKTsentr, Donetske viddilennia NTSh, "Redaktsiia hirnychoi entsyklopedii" 2009. $296 \mathrm{~s}$.

5. Rudenko I. Kolonka glavnogo redaktora // Zhurnal o metalle. 2006. \#1-7.S.3.

6. Ribas A. VII traditsionnyiy vseukrainskiy festival kuznechnogo iskusstva v Donetske // Zhurnal o metalle. 2005. \# (3-4). S. 4-9.

7. Ribas A.V chem sila tsarskoy Pektorali? // Zhurnal o metalle. 2005. \#3-4. S. 58-61.

8. Polubotko S., Polubotko O. Kuznechnyiy chempionat mira. Stia, Italiya // Zhurnal o metalle. 2005. \#3-4. S. 10-13.

9. Andrushenko S. Neprevzoydennost kovannoy mebeli // Zhurnal o metalle. 2005. \#3-4. S. 21-23.

10. Andrushenko S. Legendarnaya lichnost Kuznets / / Zhurnal o metalle. \# 3-4 (2005). S. 26-28.

11. Interview with Victor Burduk by Svitlana Rohotchenko. 11.11.2017. Kyiv.

12. Biletskyi V.S., Haiko H. I. Muzeiefikatsiia hirnychoi spravy i problema doslidzhennia istorii hirnytstva v Ukraini / / Tekhnichni muzei yak instrument zberezhennia istorychnoi spadshchyny i vazhlyvyi element rozvytku svitovoi tsyvilizatsii: materialy Mizhnar. nauk.-prakt. konf., 2-3 cherv. 2010 r., Donetsk. Donetsk, 2010. C. 25-29.

13. Palma Mertsalova. URL: https://goo.gl/bwLvsG (access date: 20.11.17).

14. Palma Mertsalova. URL: https://goo.gl/dHdSao (access date: 20.11.17).

15. Lvivska palma Mertsalova. https://www.shukach.com/uk/ node/51335 (access date: 20.11.17).

16. Styopkin V.P. Palma Mertsalova // Illyustrirovannaya istoriya Yuzovki-Stalino-Donetska. Donetsk: Apeks. 2007. S. 12.

17. Tachynskyi V. Liudy y metal // Den. 2006. \#76. 16 trav.

18. Burduk V., Rohotchenko O., Rudenko I. Khudozhnie kovalstvo Ukrainy. Kn. 1: Vidrodzhennia. Donetsk: Rehion. 2007. 120 s.: il.

19. Chernov Vitaliy Vladimirovich. URL: http://site-metall.com/ master/476-chernov-vitaliy.html (access date: 20.11.17).

\section{$\Lambda$ ітература}

1. Бердиш М. Художнє ковальство України доби незалежності [Аипломна робота на здобуття ступеня магістра]. Київ: НАОМА, 2018.

2. Боньковська С. ХуАожня обробка металу // Історія декоративного мистецтва України: У 5 т. / гол. реА. Г. Скрипник. Київ: НАН України, ІМФЕ ім. М. Т. Рильського, 2011. Т. 4. С. 161-182.

3. Волков Ф. Этнографические особенности украинского нароАа // Украинский народ в его прошлом и настоящем. ПетрограА, 1916. T. 2. С. $486-579$.

4. Гайко Г., Білещъкий В., Мікось Т., Хмура Я. Гірництво й піАземні споруди в Україні та Польщі (нариси з історії). Аонецьк: УКЦентр, Аонецьке віААілення НТШ, «РеАакція гірничої енциклопеАії» 2009. 296 c.

5. Руденко И. Колонка главного редактора // Журнал о метамме. 2006. № 1-7. С. 3.

6. Рибас A. VII традиционный всеукраинский фестиваль кузнечного искусства в Аонецке // Журнал о метамле. 2005. № (3-4). С. 4-9.

7. Рибас А. В чем сила царской Пекторали // Журнал о метамее. 2005. № 3-4. С. 58-61.

8. Полуботько С., Полуботько О. Кузнечный чемпионат мира. Стиа, Итамия // Журнам о метаме. 2005. № 3-4. С. 10-13.

9. Андрушенко С. Непревзойденность кованной мебели // Журнал о метамле. 2005. №3-4. С. 21-23.

10. Андрушенко С. Аегендарная мичность Кузнец // Журнал о металме. 2005. № 3-4. С. 26-28.

11. Інтерв'ю С. Роготченко з В. БурАуком 11.11.2017. Київ.

12. Білещький В. С., Гайко Г. І. Музеєфікація гірничої справи і проблема дослідження історії гірництва в Україні // Технічні музеї як інструмент збереження історичної спадщини і важливий елемент розвитку світової цивімізації: Матеріали Міжнар. наук.-практ. конф., 2-3 черв. 2010 р., Аонецьк. Аонецьк, 2010. С. 25-29.

13. Пальма Мерцалова. URL: https://goo.gl/bwLvsG (Аата звернення: 20.11.17).

14. Пальма Мерцалова. URL: https://goo.gl/dHdSaо (Аата звернення: 20.11.17).

15. Аьвівська пальма Мерцалова. https://www.shukach.com/uk/ node/51335 (Аата звернення: 20.11.17).

16. Стёпкин В. П. Пальма Мерцалова // Илмюстрированная история Юзовки-Сталино-Аонецка. Аонецк: Апекс. 2007. С. 12.

17. Тачинський В. Аюди й метам // Аень. 2006. № 76. 16 трав.

18. Бурдук В., Роготченко О., Руденко І. Художнє ковацьство України. Кн. 1: ВіАродження. Аонецьк: Регіон. 2007. 120 с.: іл.

19. Чернов Виталий Владимирович. URL: http://site-metall.com/ master/476-chernov-vitaliy.html (Аата обращения: 20.11.17). 


\section{Роготченко C.}

\section{ХУАожнє ковальство сходу України як складова вітчизняного культурного процесу}

Анотація. Проаналізовано розвиток ковальського ремесла і ковальської творчості у СхіАному регіоні України - Полтавській, Харківській, Аніпропетровській, Аонецькій областях. АосліАження розвитку ковальської справи у Аонецьке та Аонецькій обмасті обмежено періодом віА Аругої половини XIX сторіччя до 2014 року. Розвиток ковальства на тимчасово окупованих територіях східного регіону після початку воєнних Аій автором не досліАжується. Розглянуто і вивчено унікальний твір вітчизняного і світового ковальського мистецтва Пальму Мерцалова, що була виконана у 1895 році зі сталевої рейки ковалями Юзівського заводу «Новоросійського товариства кам'яновугільного, залізного і рейкового виробництв» Олексієм Івановичем Мерцаловим, молотобійцем Пилипом Федотовичем Шкаріним та іншими робітниками заводу. 1900 року пальма Мерцалова експонувалася на Всесвітній промислово-художній виставці у Парижі, де було представлено павільйон кам'яновугільного товариства. 1999 року у Аонецьку було встановлено першу копію пальми Мерцалова. Пальму викували донецький коваль Сергій Каспрук та його син Олег. Пальма Мерцалова стала першим в історії світового ковальства контемпорарним зразком, що привернув увагу громаАськості не Аише до твору, аме й до виробництва, де твір було виконано. 3 точки зору сучасної маркетингової науки експонування кованої пальми стало безпрецедентним явищем світового значення. Пальма Мерцалова стала стартом розвитку ковальського мистецтва на Сході України, яке піА час михоліть ХХ століття занепало і віАродимося мише на початку 1980-х років.

Ключові слова: ковальство, пальма Мерцалова, маркетинг, Парк кованих фігур.

\section{Роготченко C.}

Художественная ковка Востока Украины как составная часть отечественного культурного процесса

Аннотация. Проанализировано развитие кузнечного ремесла и кузнечного творчества в Восточном регионе Украины - в Полтавской, Харьковской, Анепропетровской, Аонецкой областях. Исследование развития кузнечного дела в Аонецке и Аонецкой области ограничено периодом со второй половины XIX века Ао 2014 года. Развитие кузнечества в восточном регионе после начала военных действий автором статьи не рассматривается. Исследовано уникальное произведение отечественного и мирового кузнечного искусства Пальма Мерцалова, которая была выполнена в 1895 году из стальной рельсы кузнецами Юзовского завода «Новороссийского общества каменноугольного, железного и рельсового производств» Алексеем Ивановичем Мерцаловым, молотобойцем Филиппом Федотовичем Шкариным и Аругими рабочими завода. В 1900 году пальма Мерцалова экспонировалась на Всемирной промышленно-художественной выставке в Париже, где была преАставлена в павильоне Новороссийского каменноугольного общества. В 1999 году в Аонецке установлена первая копия пальмы Мерцалова. Произведение выковано донецким кузнецом Сергеем Каспруком и его сыном Олегом. Пальма Мерцалова стала первым в истории мирового кузнечества контемпорарным произведением искусства, бкагодаря которому внимание общественности было направлено не только на произведение, но и на производство, где произведение было исполнено. С точки зрения современной маркетинговой науки, экспонирование кованой пальмы стало беспрецедентным явлением мирового значения. Пальма Мерцалова дала толчок развитию кузнечного искусства на Востоке Украины, которое возродилось Аишь в начале 1980-х гоАов. Ключевые слова: кузнечное искусство, пальма Мерцалова, маркетинг, Парк кованых фигур. 